\title{
AKTIVITAS ANTIHIPERTENSI EKSTRAK KERING TERSTANDARISASI KELOPAK BUNGA ROSELA (Hibiscus sabdariffa L.) HASIL PRODUKSI SKALA PILOT
}

\author{
Yasmiwar Susilawati ${ }^{*}$, Tira Soleha Rahmatullah², Ahmad Muhtadi², \\ Ferry Ferdiansyah Sofyan ${ }^{1}$, Ami Tjitraresmi ${ }^{1}$ \\ ${ }^{1}$ Departemen Biologi Farmasi Fakultas Farmasi Universitas Padjadjaran \\ ${ }^{2}$ Departemen Farmakologi, Fakultas Farmasi, Universitas Padjadjaran, \\ Jl. Raya Bandung Sumedang Km. 21 Jatinangor Sumedang \\ Email korespondensi: yasmiwar.usie@gmail.com
}

\begin{abstract}
ABSTRAK
Salah satu tumbuhan yang digunakan dalam penanganan hipertensi adalah dengan kelopak bunga rosela (Hibiscus sabdariffa L.). Penelitian sebelumnya membuktikan bahwa ekstrak etanol kelopak bunga rosela menunjukkan aktivitas antihipertensi yang signifikan $(\mathrm{P}<0,1)$ dan prospektif untuk dikembangkan. Telah dilakukan produksi ekstrak kering rosela terstandarisasi skala pilot di industri ekstrak bersertifikat IEBA. Diperlukan pengujian aktivitas antihipertensi dari ekstrak tersebut sehingga dapat diketahui dosis yang tepat untuk diaplikasikan pada manusia. Metode yang digunakan dalam penelitian ini adalah Non invasive blood pressure terhadap hewan uji tikus putih jantan galur Wistar. Penelitian ini terdiri atas 5 kelompok perlakuan yaitu kelompok kontrol negatif, dosis $150 \mathrm{mg} / \mathrm{kgBB}$; dosis $250 \mathrm{mg} / \mathrm{kgBB}$; dosis $350 \mathrm{mg} / \mathrm{kgBB}$; dan dosis $500 \mathrm{mg} / \mathrm{kgBB}$. Hasil dari penelitian menunjukkan bahwa dosis $250 \mathrm{mg} / \mathrm{kgBB}$ ekstrak kering kelopak bunga rosela (Hibiscus sabdariffa L.) memiliki aktivitas sebagai antihipertensi pada tikus putih jantan galur wistar dengan persentase inhibisi sistol dan diastol sebesar 27,74\% dan 33,18\%. Hasil konversi dosis untuk manusia yang menghasilkan efek penurunan tekanan darah pada manusia adalah dosis $2,8 \mathrm{gram} / 70 \mathrm{kgBB}$ atau $40 \mathrm{mg} / \mathrm{kgBB}$.
\end{abstract}

Kata Kunci: Antihipertensi, Skala pilot, Ekstrak Kering Kelopak Bunga Rosela (Hibiscus sabdariffa L.), Tikus.

DOI: https://doi.org/10.25026/jsk.v1i10.90

\section{PENDAHULUAN}

Hipertensi adalah suatu keadaan peningkatan tekanan darah secara terus menerus sebesar $\geq 140 / 90 \mathrm{mmHg}$, suatu kriteria ini menunjukkan resiko terhadap penyakit kardiovaskuler yang berhubungan dengan penyakit hipertensi yang cukup tinggi sehingga perlu mendapat perhatian medis (Brunton, et al, 2010).

Pada tahun 2013, sekitar 17 juta kematian setiap tahun di dunia disebabkan oleh penyakit jantung. Dari data tersebut 9,4 juta kematian setiap tahunnya disebabkan oleh komplikasi hipertensi seperti sakit jantung dan stroke. Prevalensi paling tinggi dari hipertensi ada di wilayah regional Afrika (46\%) pada umur 25 tahun ke atas, dan yang paling rendah di wilayah Amerika (35\%) (WHO, 2013).

Hasil Riset Kesehatan Dasar Indonesia pada tahun 2007, menyatakan bahwa kematian disebabkan oleh 31,9\% 
penyakit kardiovaskuler diantaranya $6,8 \%$ penyakit hipertensi dan $15,4 \%$ penyakit stroke (Rahajeng, 2009).

Berdasarkan data riset diatas maka perlu dilakukan upaya dalam penanganan penyakit hipertensi. Negara Indonesia kaya akan tumbuhan obat yang berperan dalam penyembuhan berbagai penyakit, salah satunya yaitu kelopak bunga rosela.

Kelopak bunga rosela banyak digunakan oleh masyarakat dalam mengatasi gangguan kesehatan. Aktivitas farmakologi yang ditimbulkan diantaranya sebagai ACE inhibitor (Balasuriya, 2011) yang disebabkan karena adanya senyawa delphinidin-3-osambubipside dan cyanidin-3osambubioside (Ojeda, 2010), dan diuretik (Herrera-Arrelano et al, 2007), memiliki aktivitas sebagai hepatoprotektif (Husen, 2012), memberikan perlindungan terhadap keadaan stress oksidatif yang mengalami diabetes melitus (Mohamed et al, 2013), pemberian dosis 120 $\mathrm{mg} / \mathrm{kgBB} /$ hari peroral selama 60 hari dapat menurunkan berat badan mencit yang digemukkan (Alarcon, 2007).

Berdasarkan penelitian sebelumnya pada dosis $60 \mathrm{mg} / \mathrm{kg} \mathrm{BB}$ ekstrak etanol kelopak bunga rosela memiliki aktivitas penurunan tekanan darah pada tikus putih jantan dengan inhibisi $21,9 \%$ untuk tekanan darah sistol dan nilai ini mendekati persentase inhibisi kelompok kontrol positif yaitu kaptropil dengan dosis $4,5 \mathrm{mg} / \mathrm{KgBB}$ (Ningrum et al., 2008)

Beberapa penelitian di atas menyatakan bahwa kelopak bunga rosela merupakan tanaman yang berpotensi besar sebagai salah satu herbal untuk hipertensi, maka perlu dilakukan pembuatan ekstrak skala pilot sebagai prototipe ekstrak yang akan diproduksi di industri ekstrak dalam skala yang lebih besar. Ekstrak yang dihasilkan dari skala pilot perlu dilakukan uji aktivitas antihipertensi untuk mengetahui dosis penggunaannya untuk manusia yang dapat memberikan efek optimal.

\section{METODE PENELITIAN}

Alat

Sonde oral $5 \mathrm{~mL}$, syringe $1 \mathrm{~mL}$, oscilagraph, rat tail blood pressure monitor dan alat -alat yang umum digunakan di laboratorium bahan alam

\section{Bahan}

Simplisia kelopak bunga rosela, etanol 20\%, aquadest, injeksi adrenalin 1 $\mathrm{mL}$, aqua pro injection, toluena, dan pereaksi mayer, amonia $1 \%$, asam klorida $2 \mathrm{~N}$, kloroform, pereaksi dragendorff, besi (III) klorida, larutan gelatin $1 \%$, serbuk magnesium, amil alkohol, eter, larutan vanilin $10 \%$ dalam asam sulfat pekat, pereaksi Lieberman-Burchard dan larutan $\mathrm{KOH} 5 \mathrm{~mL}$.

\section{Hewan Percobaan}

Hewan yang digunakan dalam penelitian ini adalah tikus putih jantan galur wistar dengan bobot 150-300 gram. Tikus putih jantan galur wistar diperoleh dari Institut Teknologi Bandung (ITB).

\section{Metodologi Penelitian}

\section{Pengumpulan Bahan, Sortasi dan Determinasi Tanaman}

Tanaman berupa kelopak bunga rosela diperoleh dari kota Malang, Jawa Timur sekitar bulan Agustus 2015. Sebelum dikirim ke industri yang akan melakukan proses ekstraksi, simplisia dilakukan sortasi dan kemudian dilakukan determinasi di Jurusan Biologi FMIPA UNPAD.

\section{Pembuatan Ekstrak Kering Kelopak Bunga Rosela \\ Ekstrak kering kelopak bunga rosela diproduksi oleh PT. Phytochemindo Reksa Gunung Putri Bogor. Proses ekstraksi menggunakan pelarut etanol $20 \%$.}




\section{Penetapan Kadar Air Ekstrak Kering Kelopak Bunga Rosela Hasil Produksi Skala Pilot}

Toluena $200 \mathrm{~mL}$ dimasukan ke dalam labu alas bundar kemudian ditambahkan air sebanyak $2 \mathrm{~mL}$ dan dijenuhkan \pm 2 jam. Setelah jenuh kemudian 40 gram ekstrak kering dimasukkan kedalam labu alas bundar dan didestilasi sehingga air terpisah dan dihitung kadar air dalam ekstrak.

\section{Pengujian Aktivitas Antihipertensi: Pengukuran Tekanan Darah Awal (TD} I)

Seluruh protokol pengujian aktivitas antihipertensi in vivo pada pengujian ini telah mendapat persetujuan etik dari Komisi Etik Penelitian Kesehatan.

Aktivitas antihipertensi ini dilakukan dengan menggunakan metode Non-Invasive Blood Pressure dengan alat CODA $^{\mathrm{TM}}$ Kent Scientific Corporation terhadap tikus putih galur wistar.

Tekanan darah awal diukur sebelum tikus putih jantan galur wistar diinduksi dengan injeksi adrenalin. Tekanan darah ini dicatat dan dinyatakan sebagai nilai tekanan darah pre-test atau TD I.

\section{Pengukuran Tekanan Darah Setelah Induksi Adrenalin}

Setelah tekanan darah normal tikus dicatat, kemudian tikus diinduksi dengan larutan adrenalin dosis $1,2 \mu \mathrm{g} / \mathrm{Kg}$ BB i.p untuk mencapai keadaan hipertensi. Kemudian tekanan darah tikus setelah induksi diukur kembali, dan diperoleh tekanan darah tinggi atau tekanan darah saat hipertensi yaitu TD II.

\section{Pemberian Sediaan Larutan Uji}

Tekanan darah tikus kembali normal sekitar 50-60 menit, kemudian tikus diberikan larutan uji dengan dosis yang telah ditentukan secara peroral, dibiarkan selama 15 menit lalu diberikan adrenalin secara intraperitonial. Setelah ditunggu 15 menit tekana darah diukur kembali dan dicatat sebagai tekanan darah akhir yaitu TD III.

\section{Perhitungan Aktivitas Antihipertensi}

Aktivitas antihipertensi kelompok uji ditunjukkan oleh persentase penurunan tekanan darah atau persen inhibisi dengan menggunakan rumus berikut:

Penurunan tekanan darah $=$ TD II - TD III $\%$ inhibisi $=\frac{\text { TD II }- \text { TD III }}{\text { TD II }} \times 100 \%$

Keterangan:

$\begin{array}{rlr}\text { TD II = } & \begin{array}{l}\text { Tekanan darah setelah } \\ \text { diinduksi dengan adrenalin } \\ \text { (mmHg). }\end{array} \\ \text { TD III = } & \begin{array}{ll}\text { Tekanan darah setelah diberi } \\ \text { larutan ekstrak } & \text { kering } \\ & \text { kelopak bunga rosela } \\ & (\mathrm{mmHg}) .\end{array}\end{array}$

\section{Analisis Data}

Data hasil pengukuran tekanan darah tikus selanjutnya dianalisis secara statistika menggunakan desain Analisis Varian (ANAVA) model tetap pada taraf nyata 0,05 dan 0,01 serta dilakukan uji rentang Newman-Keuls.

\section{HASIL DAN PEMBAHASAN}

Tanaman yang digunakan dalam penelitian ini berupa kelopak bunga rosela (Hibiscus sabdariffa L.) yang diperoleh dari kota Malang, Jawa Timur. Tumbuhan rosela dideterminasi di Jurusan Biologi FMIPA UNPAD.

\section{Hasil Ekstraksi Ekstrak Kering Kelopak Bunga Rosela Hasil Produksi Skala Pilot}

Ekstrak yang digunakan dalam penelitian ini adalah ekstrak kering kelopak bunga rosella yang hasil produksi skala pilot yang diperoleh dari PT. Phytochemindo Reksa, Gunung Putri Bogor. Sebanyak $100 \mathrm{~kg}$ simplisia di ekstraksi dengan menggunakan pelarut etanol $20 \%$. 
Ekstrak kering kelopak bunga rosela mengandung 25\% ekstrak kelopak bunga rosela dan $75 \%$ laktosa. Ekstrak kering kelopak bunga rosela secara organoleptis berwarna merah-cokelat, berbentuk serbuk, dan memiliki sifat higroskopis jika dibiarkan dalam udara terbuka. Ekstrak kering kelopak bunga rosela memiliki sifat mudah larut di dalam air

Hasil penetapan kadar air ekstrak kering kelopak bunga rosela hasil produksi skala pilot yang diperoleh adalah $0,5 \%$ sehingga memenuhi syarat kadar air ekstrak kering menurut standar Farmakope Herbal Indonesia.

\section{Hasil Pengujian Kromatografi Lapis Tipis Ekstrak Kering Kelopak Bunga Rosela Hasil Produksi Skala Pilot}

Berikut adalah hasil KLT ekstrak kering menggunakan plat silika gel $\mathrm{GF}_{254}$ dengan pengembang $n$-butanol : asam asetat glasial : air (4:1:5). Kromatogram menunjukkan adanya bercak pada $\mathrm{R} f$ $0,306,0,431$, dan 0,715. Ketiga bercak terdeteksi pada ekstrak hasil skala lab maupun ekstrak hasil skala pilot. Hal ini menunjukkan bahwa proses pembuatan ekstrak skala pilot tidak merubah komponen kimia dalam ekstrak.

\section{Pengujian Aktivitas Antihipertensi Ekstrak Kering Kelopak Bunga Rosela Hasil Produksi Skala Pilot}

Penelitian ini bertujuan untuk mengetahui aktivitas antihipertensi dan mendapatkan dosis terbaik dari ekstrak kering kelopak bunga rosela hasil produksi skala pilot yang dapat memberikan aktivitas sebagai antihipertensi yang optimal.

Dosis uji yang diberikan pada hewan coba adalah 4(empat) variasi dosis, yaitu: $150,250,350$ dan $500 \mathrm{mg} / \mathrm{kgBB}$. Penentuan dosis berdasarkan hasil penelitian Ningrum et al. (2008) yang menyatakan bahwa dosis efektif untuk penurunan aktivitas antihipertensi adalah $60 \mathrm{mg} / \mathrm{kgBB}$ dimana persentase inhibisi penurunan tekanan darah yang ditimbulkan mendekati persentase dari pemberian obat standar, yaitu kaptropil dengan dosis $4,5 \mathrm{mg} / \mathrm{kgBB}$ dan hasil yang diperoleh dari penelitian tersebut tidak menimbulkan hipotensi dimana penurunan tekanan darah ada dalam kisaran normal.

Dikarenakan kandungan ekstrak dalam sampel adalah 25\%, maka penentuan dosis-dosis dihitung secara konversi dari dosis sebelumnya, sehingga dosis $60 \mathrm{mg} / \mathrm{kg}$ BB sebanding dengan dosis $250 \mathrm{mg} / \mathrm{kgBB}$ ekstrak kering. Sehingga dosis $250 \mathrm{mg} / \mathrm{kgBB}$ ekstrak kering kelopak rosela memiliki aktivitas antihipertensi terbaik (dosis efektif). Dosis 150,350 dan $500 \mathrm{mg} / \mathrm{kgBB}$ dibuat sebagai variasi dari hipotesa dosis efektif.

Untuk mengetahui aktivitas mana yang terbaik maka dari data hasil pengukuran darah sebelumnya yaitu pengukuran TD I dan TD II selanjutnya dilakukan perhitungan aktivitas penurunan tekanan darah sistol dan diastol (\% inhibisi) dan disajikan dalam Gambar 1.

\section{Penurunan Tekanan Sistol}

Berdasarkan Gambar 1. persen inhibisi aktivitas penurunan tekanan darah sistol setelah pemberian larutan uji yang paling tinggi dihasilkan oleh larutan ekstrak kering kelopak bunga rosela pada dosis $2(250 \quad \mathrm{mg} / \mathrm{kgBB})$. Persentase penurunan ini paling tinggi jika dibandingkan dengan dosis 1, 3, 4, dan kontrol negatif. Sedangkan persen inhibisi aktivitas penurunan tekanan darah sistol setelah pemberian sediaan uji yang paling rendah dihasilkan oleh kontrol negatif. Persentase penurunan ini paling rendah jika dibandingkan dengan dosis 1, 2, 3, dan dosis 4 . 


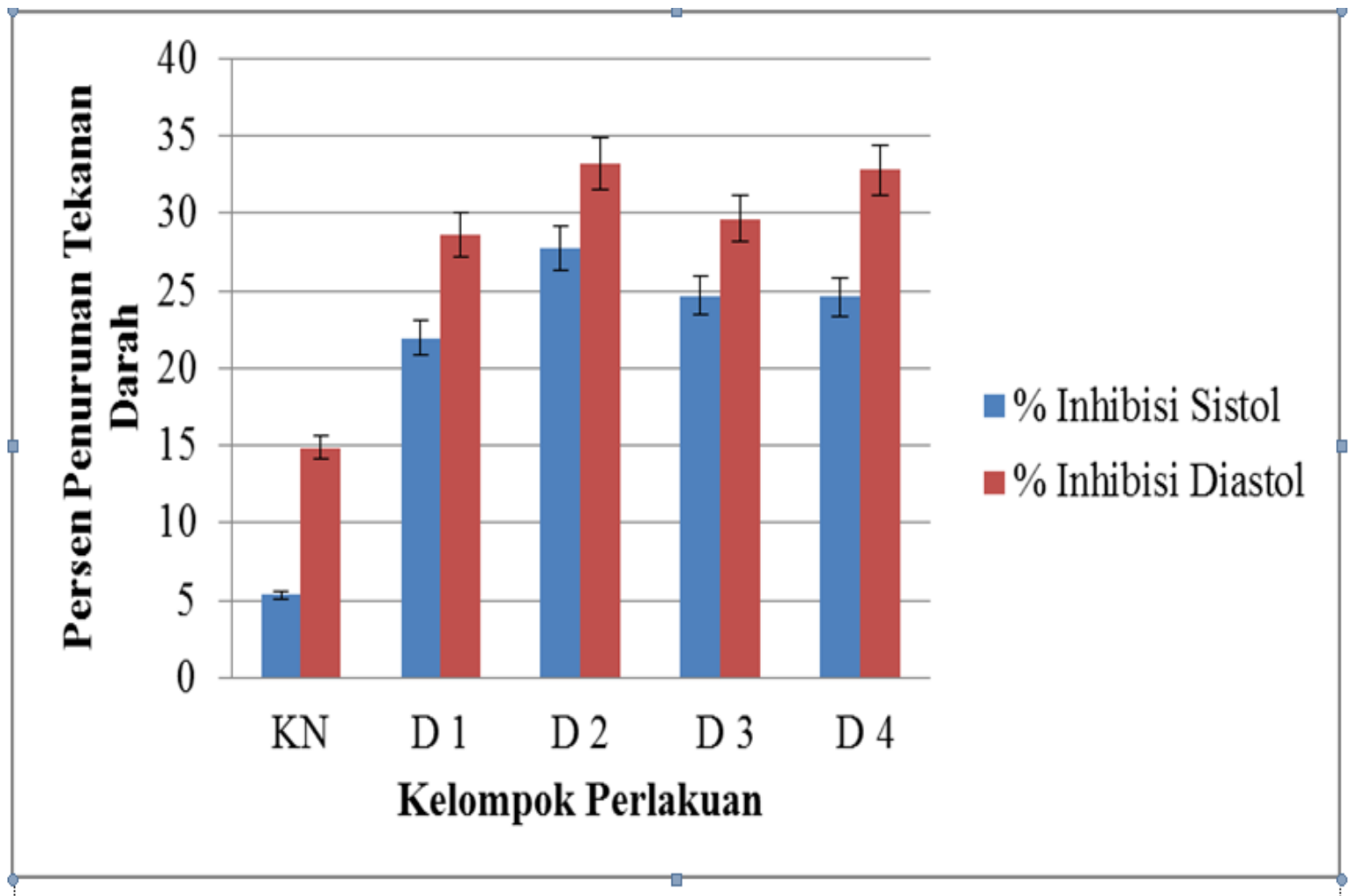

Gambar 1. Persen inhibisi aktivitas penurunan tekanan darah.

Keterangan:

KN : Diberi Aquadest $2 \mathrm{~mL} / \mathrm{kgBB}$

D 1 : Ekstrak Kering Kelopak Bunga Rosela $150 \mathrm{mg} / \mathrm{kgBB}$

D 2 : Ekstrak Kering Kelopak Bunga Rosela $250 \mathrm{mg} / \mathrm{kgBB}$

D 3 : Ekstrak Kering Kelopak Bunga Rosela $350 \mathrm{mg} / \mathrm{kgBB}$

D 4 : Ekstrak Kering Kelopak Bunga Rosela 500 mg/kgBB

\section{Penurunan Tekanan Diastol}

Berdasarkan Gambar 1. persen inhibisi aktivitas penurunan tekanan darah diastol setelah pemberian larutan uji yang paling tinggi dihasilkan oleh larutan ekstrak kering kelopak bunga rosela pada dosis $2 \quad(250 \quad \mathrm{mg} / \mathrm{kgBB})$. Persentase penurunan ini paling tinggi jika dibandingkan dengan dosis 1, 3, dosis 4, dan kontrol negatif. Sedangkan persen inhibisi aktivitas penurunan tekanan darah diastol setelah pemberian sediaan uji yang paling rendah dihasilkan oleh kontrol negatif dimana tikus hanya diberi aquadest $2 \mathrm{~mL} / \mathrm{kgBB}$. Persentase penurunan ini paling rendah jika dibandingkan dengan dosis 1, 2, 3, dan dosis 4 .

Hal ini menunjukkan kelompok dosis 2 memberikan aktivitas antihipertensi. Persentase penurunan tekanan darah sistol dan diastol kelompok dosis 2 menunjukkan nilai yang paling tinggi dibandingkan dengan kelompok perlakuan yang lainnya.

\section{ANALISIS DATA STATISTIK}

Dari hasil analisis varian menggunakan SPSS IBM SPSS Statistics 20 signifikansi tekanan darah sistol dan diastol adalah 0,000 yang berarti nilai signifikansi tersebut adalah kurang dari 0,05 (taraf kepercayaan 5\%) dan kurang dari 0,01 (taraf kepercayaan 1\%). Sehingga dapat dinyatakan $\mathrm{H}_{0}$ ditolak yang artinya sebesar 95\% dan 99\% pemberian larutan ekstrak kering kelopak bunga rosela memiliki pengaruh terhadap penurunan tekanan darah sistol dan diastol. Selanjutnya dilakukan uji lanjut Newman Keuls. Uji lanjut ini bertujuan 
untuk mengetahui dosis mana yang memiliki perbedaan aktivitas signifikan pada keyakinan $95 \%$ dan $99 \%$.

Hasil uji Newman Keuls persentase penurunana tekanan darah sistol kelompok kontrol negatif menempati subset 1 artinya menghasilkan pengaruh yang berbeda dengan dosis 1, 2, 3, dan 4 . Dosis 1, 3, dan 4 menempati subset 2 yang berarti mengasilkan pengaruh yang sama antara dosis 1, 3, dan 4 namun memiliki pengaruh yang berbeda dengan kontrol negatif dan dosis 2. Selanjutnya dosis 2, 3, dan 4 menempati subset ke 3 yang berarti menghasilkan pengaruh yang sama antara dosis 2, 3, dan 4 namun menghasilkan pengaruh yang berbeda terhadap dosis 1 dan kontrol negatif.

Hasil uji Newman Keuls persentase penurunanan tekanan darah diastol kelompok kontrol Negatif menempati subset 1 artinya menghasilkan pengaruh yang berbeda dengan dosis 1, 2, 3, dan 4 . Dosis 1, 2, 3, dan 4 menempati subset 2 yang berarti menghasilkan pengaruh yang sama antara dosis $1,2,3$, dan 4 namun memiliki pengaruh yang berbeda dengan kontrol negatif.

Hasil uji lanjut menggunakan Newman Keuls dapat dinyatakan bahwa secara statistik terdapat perbedaan signifikan dari kelompok perlakuan yang diberikan terhadap penurunan tekanan darah sistol dan diastol.

\section{SIMPULAN DAN SARAN}

\section{Simpulan}

Ekstrak kering kelopak bunga rosela (H. sabdariffa L.) hasil produksi skala pilot memiliki aktivitas antihipertensi terhadap tikus putih jantan galur wistar.

Dosis $250 \mathrm{mg} / \mathrm{kgBB}$ ekstrak kering kelopak bunga rosela $(H$. sabdariffa L.) memiliki aktivitas sebagai antihipertensi dengan persentase inhibisi sistol dan diastol sebesar $27,74 \%$ dan 33,18 \%. Hasil konversi dosis untuk manusia yang menghasilkan efek penurunan tekanan darah pada manusia adalah dosis 2,8 gram/70 $\mathrm{kgBB}$ atau 40 $\mathrm{mg} / \mathrm{kgBB}$.

\section{Saran}

Perlu dilakukan uji keamanan dan toksisitas ekstrak kering kelopak bunga rosela. Selain itu perlu dilakukan studi formulasi sediaan farmasi yang tidak mengganggu kestabilan dari ekstrak kering kelopak bunga rosela hasil produksi skala pilot. Salah satu rekomendasi bentuk sediaan yang dapat dibuat adalah sediaan serbuk seduh dan tablet.

\section{DAFTAR PUSTAKA}

Alarcon, A. F.J., Zamilpa, A.M., Perez, G. D., Almanza, P. J.C., Romero, N. E., Campos, S. E.A, Vazquez, C. L.I., and Roman, R. R. 2007. Effect of Hibiscus sabdariffa on Obesity in MSG Mice. J. Ethnopharmacol. 114(1): 66-71.

Balasuriya, B. W. And Rupasingle, H. P. V. 2011. Plant Flavonoids as Angiotensin Converting Enzyme Inhibitors in Regulation of Hypertension. Functional Foods in Health and Disease.5:172-188.

Bruneton, Laurence. Parker Keith. Blumenthal Donald., Lain Buxton. 2010. Goodman \& Gilman Manual Farmakologi dan Terapi. Jakarta: Penerbit Buku kedokteran EGC. 507

Herrera, A. A, Miranda, S. J., Avila, C. P., Harrera, A. S., Jimenez, F. J. et al., 2007. Clinical Effects Produced by a Standardized Herbal Medicinal Product of Hibiscus sabdariffa on Patient with Hypertension. A Randomized, Double-blind, Lisinopril-Controlled Clinical Trial. Planta Med. 73: 6-12.

Husen, I. R., Sastramihardja, H. S. 2012. Efek Hepatoprotektif Rosella (Hibiscus sabdariffa L.) pada Tikus Model Hepatitis Vol. 44 No. 2. Bandung: Departemen Farmakologi 
\& Terapi Fakultas Kedokteran Universitas Padjadjaran.

Mohamed, Jamaludin., Shing Saw Wuang., Idris Muhd Hanis Md., Budin Siti Balkis., Zainalabidin Satirah. 2013. The Protective effect of aqueous extracts of roselle (Hibiscus sabdariffa L. UKMR-2) Against Red Blood Cell Membrane Oxsidative Stress in Rats With Streptozotocin-Induced Diabetes. Basic Research Clinics. 68(10): 1358-1363.

Ningrum, L., Y., Y. Susilawati, dan S.A. Sumiwi. 2008. Aktivitas Antihipertensi Ekstrak Etanol Kelopak Bunga Rosela (Hibiscus sabdariffa L.) Pada Tikus Putih Jantan. [Skripsi]. Jatinangor: Fakultas Farmasi Universitas Padjadjaran.
Ojeda, D. Ferrer, E. J., Zamilpa, A. Arellano, A. H. Tortoriello, J. Alvarez, L. 2012. Inhibition of Angiotension Convertion Enzyme (ACE) Activity by The Anthocyanins Delphinidin-and Cyanidin-3-osambubiosides from Hibiscus sabdariffa. J. Ethnopharmacol. 127: 7-10.

Rahajeng, Ekowati dan S. Tuminah. 2009. Prevalensi Hipertensi dan Determinasinya di Indonesia. Majalah Kedokteran Indonesia. 59(12): 580-587.

WHO. 2013. A Global Brief on Hypertension: Silent Killer, Global Public Health Crisis. Available online at http://apps.who.int/iris/bitstream/10 665/79059/1/WHO_DCO_WHD_2 013.2_eng.pdf (Diakses pada tanggal 31 Agustus 2015). 